Department of Cardio-angiology, Kitasato University School of Medicine

1-15-1 Kitasato, Minami-ku, Sagamihara, Kanagawa 252-0373, Japan

J Jpn Soc Intensive Care Med 2011;18:8 10.

\section{文 献}

1) 班長 : 和泉 徹. 循環器病の診断と治療に関するガイドラ イン (2008年度合同研究班報告) 急性および慢性心筋炎 の診断・治療に関するガイドライン (2009年改訂版).
Available from: http://www.j-circ.or.jp/guideline/pdf/ JCS2009_izumi_h.pdf

2) Shiotsuka J, Nishina H, Sanui M, et al. Atypical late gadolinium enhancement and left ventricular aneurysm secondary to acute myocarditis. J Jpn Soc Intensive Care Med 2011;18:73-6.

3) Friedrich MG, Sechtem U, Schulz-Menger J, et al; International Consensus Group on Cardiovascular Magnetic Resonance in Myocarditis. Cardiovascular magnetic resonance in myocarditis: A JACC White Paper. J Am Coll Cardiol 2009;53:1475-87.

受付日 2010 年 5 月 6 日 採択日 2010 年 5 月 7 日

\title{
両心補助人工心臓により救命し得た劇症型心筋炎 一補助人工心臓装着のタイミングと問題点
}

\section{はじめに}

心筋炎は,「心室収縮機能障害をもたらす心筋の炎 症」と定義され，急性心不全の約 $10 \%$ を占めると考元 られている1)。そのうち, 劇症型心筋炎は, 「血行動態 の破綻を急激に来たし, 致死的経過をとる急性心筋炎」 と定義される。欧米では, 強心薬の静脈内投与を必要 とする症例も劇症型心筋炎とみなされることが多い が, 本邦では主に「体外補助循環を必要とした重症度 を有する」心筋炎と定義されている2)。発症初期より 血行動態の破綻を来たすものから, 腹部症状のみ呈し 歩いて外来を受診し，その後時間単位で急激に増悪す るものまで, 様々な表現を示す症例が存在する。基本 的には，一部を除き特異的な治療法はない。多くはウ イルス感染によるものと考えられ，心筋炎極期を乗り 切りさえすれば，自然軽快し予後は良好とされる3)。 自然回復の時期まで全身を支えるため, 強心薬のみな らず積極的に補助循環を使用することとなる。

長谷川らの報告にある症例は4), 先行する感冒様症 状を伴う若年女性が全身倦急感を訴え，近医受診した ところ, 壁運動異常を認め急性心筋炎と診断され, 強 心薬, 大動脈内バルーンパンピング (intra-aortic balloon pumping, IABP) 挿入後も循環動態が維持で きなかったため搬送された患者である。来院時は，血 圧が維持されずショック状態であり，ただちに人工呼 吸, ペーシング, 持続的血液滤過透析 (continuous hemodiafiltration, CHDF)，そして経皮的心肺補助装 置 (percutaneous cardiopulmonary support, PCPS) を装着された。しかし, 強心薬を極量投与しても臟器 障害所見が見られたため, 第5病日に左室に補助人工 心臓 (ventricular assist device, VAD), そして右心系 も遠心ポンプによる補助を行った。その後, 全身状態, 心機能とも改善し, 術後11日目に補助循環から離脱, 術後29日目にICU退室, 術後102日目に独歩退院と なった症例である。経過中，現場は報告には表れない 苦悩の連続であっただろうと推察される。大変な症例 を救命された現場の努力に敬意を表する。

\section{劇症型心筋炎における補助循環の適応}

劇症型心筋炎における補助循環の適応は, (1)心静止 を含む致死性不整脈と，(2)心ポンプ失調による低心拍 出量状態の 2 つである2)。後者に関して, 多くの場合, スピードはともかく, 低心拍出量が段階的に進行する ため, 強心薬, IABP, PCPS と治療を強化することが 
多い。我々内科医は, PCPSまでは自分たちの力で装 着が可能であり, その適応や離脱について, ある程度 の「感覚」を持っている。しかし，VADの装着は外科 に依頼する必要があり, 離脱も手術が必要であること より, PCPS装着判断時よりさらに厳しい状況に追い 达まれて初めて考虑することが多いように思われる。 PCPSから VADへの移行を考えざるを得ない理由は,

(1)下肢阻血, 挿入部出血・血腫などIABP ・ PCPS装 着に関する合併症

(2)人工肺劣化, 溶血など装着後の合併症

(3)拍出量不足による多臟器不全

である。また，一般論として，PCPSはその作動状況 より後負荷の増大をもたらし, 前負荷軽滅効果はある とはいえ, 心機能回復にはマイナスとなる場合もある。

長谷川らの症例は, (1)は認められないものの, 頻回 の人工肺交換, 溶血所見など(2)の所見, 血小板数減少, さらに総ビリルビン上昇, $\mathrm{CHDF}$ への移行など(3)の所 見は著明であり, 左室補助循環への移行は適切であっ たと考えられる。また, 本症例のターニングポイント は, 右室遠心ポンプ補助を併用したところである。左 室補助循環のみでは血行動態を維持できず,ドパミン， ドブタミン,ノルアドレナリンを最大量投与している ことも併せると, 右室遠心ポンプ補助装着はやむを得 ない。Reinhartzらは, VAD装着後の症例では, 直接 および間接ビリルビン值が予後規定因子であったと報 告している5)。これについては, 全米のVAD registry であるINTERMACSからの報告でも裏付けられてい る6)。そのためUnosawaらは, ビリルビンが上昇する 以前である 3 日目からの左室 VAD装着を行い, 同様 の劇症型心筋炎の救命に成功したと報告している7)。 本症例のように, すでにビリルビンが上昇してしまっ てからのVAD装着になった場合は, より積極的に右 室の負荷軽減とサポートを行うべきであろう。

\section{VAD移行への問題点と今後の対応}

では, 現実問題として, 本邦の医療現場にてVADへ 移行するために考虑すべき, あるいは改善すべき問題 点について記述する。

\section{1）より簡易に使用できる体外式VAD}

劇症型心筋炎では, 全身状態が悪いときの装着とな る点, 短期間の使用となることが期待されている点, かつ両室補助が必要となることが多い点より, 植込み 型より体外式のほうが望まれる。現在本邦で使用可能 なVADは体外式 (TOYOBO, ゼオン型)であり,この 目的には適している。しかし, これらのVADはすで に旧式であり, 送血管, 脱血管とも太く, 血栓形成, 感
染の機会も多い。近年, 欧米ではTandemHeart ${ }^{\circledR}$ (Cardiac Assist社, USA), CentriMag ${ }^{\circledR}$ (Levitronix 社, Switzerland）といった, より簡易に抻入でき, 合 併症が少なく短期間の観察が可能な器具が使用されて いる。これらが本邦でも使用可能になれば，より早期 の装着, 場合によればPCPSをスキップし, より全身 状態の良い状態での装着が望めるようになる。

\section{2) 心筋生検のタイミング}

長谷川らの報告にある症例の問題点は, 心筋生検が 行われていないことである。劇症型心筋炎には特異的 治療法はない, と前述したが, 唯一効果が期待できる 方法は, 巨細胞性心筋炎, 好酸球性心筋炎における テロイド投与を基本とした免疫抑制療法である。特に 好酸球性心筋症に対しては, ステロイドは劇的な効果 を示す8)。当院でも, 過去に迅速な心筋生検にて, ス テロイドにより劇的な改善を認めた好酸球性心筋炎を 経験した一方, 全身状態が非常に悪いショック状態で 来院された症例に緊急にVADを装着すると, その心 筋サンプルから好酸球の浸潤が確認され, ステロイド 投与の夕イミングを逸した症例を経験した。VAD装 着となると，体外式はもとより，たとえ植込み型であ ろうともバッテリーケーブルは体外へ出ているため, 長期ステロイド投与による挿入部の感染は必発であ る。よっていかなる状況でも, できればV $\mathrm{AD}$ 装着前 に心筋生検を行うように努力をする必要がある。当院 では現在, 必ず来院時, また遅くても翌日に行うよう に努めている。

\section{3）VAD離脱，心臟移植への移行に関する問題点}

劇症型心筋炎は比較的予後が良い, と前述した。 Guptaらの論文1にも,VADを装着した $50 \%$ 以上の症 例はVAD離脱に十分なほどの心機能改善を示した, と記載されている。しかし, 逆に考えると $50 \%$ 以下の 症例は, VAD離脱が困難であったということになる。 他国では, これらの症例は心臓移植を行えば良い, と なるが本邦では, 心臟移植実施件数は年間 10 例に満た ず, 待機期間は 3 年を超えることより, 簡単にそのよ うなことは言えない。本来はVADを装着する際に, 「離脱できなかった場合移植を受けるのか」とともに, $\lceil\mathrm{VAD}$ 装着したまま 3 年間病院に入院し続けるがそ れで良いのか」も本人に確認すべきであるが，それが 行えず, やむなく家族との話し合いで決定されている のが現状である。これを解決するには, 移植件数を増 やす努力, より生活の質 (quality of life, QOL)の高い 形で安全に移植を待機できるVADを導入する努力と ともに, 心機能改善についてょり正確な予測をする努 力が必要となる。移植件数に関しては, 2010年 7 月よ 
り新しい臟器移植法案が施行され, 移植件数は増加す ると予測される。また，今後保険収載が予測される植 込み型VADは外来で待機が可能であり, 待機患者の QOL 向上に寄与すると考えられる。一方, 心機能改善 に寄与する生存心筋評価について, 十分に進歩したと は言い難いのが現状であり，この分野の精力的な努力 が望まれる。

\section{坂田 泰史}

大阪大学大学院医学系研究科循環器内科学

（干 565-0871 大阪府吹田市山田丘2-2）

A case of fulminant myocarditis successfully treated using a biventricular assist device - when should VAD be implanted and what should be considered?

Key words: (1) myocarditis, (2) ventricular assist device, (3) transplantation

\section{Yasushi Sakata}

Department of Cardiovascular Medicine, Osaka University Graduate School of Medicine

2-2 Yamadaoka, Suita, Osaka 565-0871, Japan

J Jpn Soc Intensive Care Med 2011;18:10 12.

\section{文 献}

1) Gupta S, Markham DW, Drazner MH, et al. Fulminant myocarditis. Nat Clin Pract Cardiovasc Med 2008;5:693706.

2) 班長 : 和泉 徹. 循環器病の診断と治療に関するガイドラ イン (2008年度合同研究班報告） 急性㧍よび慢性心筋炎 の診断・治療に関するガイドライン (2009年改訂版). Available from: http://www.j-circ.or.jp/guideline/pdf/ JCS2009_izumi_h.pdf

3) McCarthy RE 3rd, Boehmer JP, Hruban RH, et al. Long-term outcome of fulminant myocarditis as compared with acute (nonfulminant) myocarditis. N Engl J Med 2000;342:690-5.

4) 長谷川豊, 江連雅彦, 佐藤泰史, 他. 両心補助人工心臟に より救命し得た劇症型心筋炎の1例。 日集中医誌 2011 ; 18:77-82.

5) Reinhartz O, Farrar DJ, Hershon JH, et al. Importance of preoperative liver function as a predictor of survival in patients supported with Thoratec ventricular assist devices as a bridge to transplantation. J Thorac Cardiovasc Surg 1998;116:633-40.

6) Kirklin JK, Naftel DC, Kormos RL, et al. Second INTERMACS annual report: more than 1,000 primary left ventricular assist device implants. J Heart Lung Transplant 2010;29:1-10.

7) Unosawa S, Hata M, Sezai A, et al. Successful management of fulminant myocarditis with left ventricular assist device: report of a severe case. Ann Thorac Cardiovasc Surg 2010;16:48-51.

8) Imran SS, Tan KB, Chee LS, et al. Eosinophilic myocarditis: an unusual presentation. J Am Coll Cardiol 2010;55:254 